\title{
Environmental Benefits from the Use of Vegetable Materials in Building Construction: Case Study in the South of Portugal
}

\author{
P. Mendonça and F. Amorim
}

\begin{abstract}
This paper aims to show the environmental benefits from using vegetable materials, such as timber and straw, in alternative to conventional industrialized materials, such as brick, concrete and steel in building construction. Vegetable materials can present significant economic and environmental advantages, as they represent an abundant and renewable resource with very low embodied energy. To illustrate these benefits it is used as case study a traditional house dwelling from Carrasqueira, a Sado river coastal village in the south of Portugal. This dwelling, made with thatched straw and a timber structure in both walls and roofs, is compared with two dwellings of the same area and plan configuration: one using a traditional stone external wall aiming to characterize the most representative portuguese traditional constructive system for vernacular housing; and the other one using the conventional exterior wall solution in hollow brick with post and beam concrete structure aiming to characterize the contemporary constructive system commonly used in housing buildings construction in Portugal.
\end{abstract}

Index Terms-Environmental assessment, building materials, thatched straw, clay brick, stone.

\section{INTRODUCTION}

This paper presents a research about the use of vegetable materials in construction, focusing on a case study about the traditional straw hut of Carrasqueira, one of the rare portuguese vernacular buildings made almost entirely in vegetable materials. An environmental assessment to this building is presented in order to understand how the use of vegetable materials assembled with traditional techniques can allow the reduction of the environmental impact of construction when compared to conventional construction.

Following a previous study by Mendonça [1], it could be concluded that clay brick, blocks and tiles accounts for almost $40 \%$ of the Embodied Energy (EE) of all the materials used in a conventional construction building in Portugal, and especially due to the clay bricks used on exterior walls, as it can be seen on Fig. 1. Thus, for obtaining less environmental impacting buildings, the consideration of materials with less EE than clay brick and tiles should be pondered. That's the

Manuscript received May 30, 2015; revised July 29, 2015. This work has financial support from the Project UID/AUR/04509/2013 by FCTMEC by national funding and, when applicable, FEDER co-financing under the new PT2020 partnership agreement.

P. Mendonça is with Lab2PT Research Centre, School of Architecture, University of Minho, Azurém Campus, 4800-058 Guimarães, Portugal (e-mail: mendonca@ arquitectura.uminho.pt).

F. Amorim is with School of Architecture, University of Minho, Azurém Campus, 4800-058 Guimarães, Portugal (e-mail: a61621@alunos.uminho.pt). case of the traditional thatched straw huts of Carrasqueira village, the solution here presented and analyzed in comparison with a theoretical conventional hollow brick masonry dwelling and a traditional stone masonry dwelling, both configured to an equal area and plan layout in order to allow this comparison.

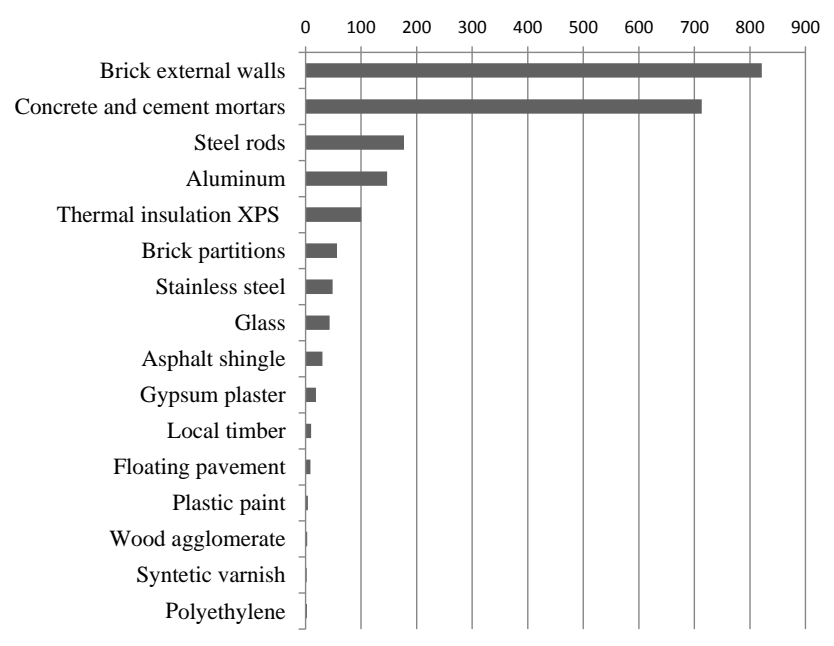

Fig. 1. Embodied energy of materials used in a typical Portuguese contemporary building, in $\mathrm{kWh} / \mathrm{m}^{2}[1]$.

\section{Characterization OF HOUSING IN THE SOUTH OF PORTUGAL}

The housing stock in Portugal grew at an average annual rate of over $1 \%$ till 2008 , but from that year on the growth rates have been declining. In 2013 the growth was just 0,3\% in relation to the previous year [2]. The new residential dwelling permits issued decreased by $35,2 \%$ over 2012 , corresponding to 7.286 dwelling permits in 2013. These numbers reflect the fact that Portugal has already about 5.9 million dwellings, largely enough to fulfill the housing needs of its 10,46 million population. The average number of inhabitants by dwelling in Alentejo (the biggest portuguese south region in territorial area) is one of the lowest in Portugal, with 1,6, in pair with the center region. Only Algarve (the southern coastal area of Portuguese territory) presents a lower value, with 1,2 [2]. However, this contradicts the fact that Algarve was the area that registered the most significant increase in the number of dwellings from 2012 to 2013 (19\%). A reasonable explanation for this fact is the growing importance of touristic demand in this region, being many buildings subject to a seasonal use (second home) or just for rent. This region is the only in Portugal in which predominates the two bedroom typologies, as in the rest of the territory always predominates the three bedroom 
typology, which also corroborates the previously referred explanation. New constructions are still predominant, representing $58,2 \%$ of the total licensed buildings in 2013 [2] while in 2008 new constructions represented $72,3 \%$ of the total, what shows a significant tendency of decrease in new constructions and increase in refurbishing. Algarve, Centre and Alentejo regions present the higher proportion of refurbishing in Portugal with values of $31,5 \%, 31,9 \%$ and $43,2 \%$, respectively [2].

\section{CONSTRUCTION INDUSTRY IN PORTUGAL}

A construction boom took place in Portugal during the $80 \mathrm{~s}$ and 90 s decades of the past century, most of buildings made without a sustainable cost/benefit ratio due to initial budget limitations, but also to a lack of environmental consciousness and legislation. Nowadays, new quality and legal constraints, especially related with the implementation of Energetic Certification, following European directives, are conducting to relevant changes, especially regarding building thermal performance. However, the legislation and concerns about environmental impacts related with the construction and demolition phases are still much neglected [3]. In this paper, some environmental impact indicators related with the construction phase are assessed and a case study is presented comparing the straw huts of Carrasqueira with the conventional contemporary (clay brick and reinforced concrete) and traditional (stone masonry) portuguese constructive solutions.

\section{A. Clay Bricks, Blocks and Tiles}

The most common building construction system applied nowadays in Portugal is the post and beam concrete structure with clay hollow brick walls and hollow blocks on slabs. The clay hollow bricks, hollow blocks and tiles are available in the Portuguese territory; however the industries are concentrated mainly in the littoral center of the country (Fig. 2 a) ). The biggest production is concentrated along the central coastal strip, in the Lisbon and Tagus valley region (South region), Aveiro and Leiria (Centre region) respectively, whose summed values represent almost the total national production, approximately 90\%. In 2000 Portugal was the $5^{\text {th }}$ biggest producer in Europe (in absolute number) and the $1^{\text {st }}$ if considered the production per-capita [1]. The south of Portugal accounts for about $45 \%$ of the total national clay bricks, blocks and tiles production. However, it is mainly concentrated in the Lisbon and Tagus river valley (Fig. 2 a) ).

\section{B. Stone}

The conventional traditional solution, comprising massive stone masonry walls and timber roof structures was also assessed. Due to the lack of efficient means of transportation, the materials used in the walls of traditional houses, mostly heavy in the portuguese context, were, till the beginning of the $\mathrm{XX}^{\text {th }}$ century, closely associated with the local availability of raw materials [1]. The stone industry is still nowadays very connected to the presence of natural resources and still reflected in the profuse use of stone in building construction, however using building systems and technologies quite different than the massive stone masonry walls of the past. In spite of its small territorial dimension when compared with the other countries on this ranking, Portugal is among the world's top ten natural quarry stone producers, as it can be seen on Table I. The output of the top ten quarry stone producing countries collectively accounted for $92.6 \%$ of world quarry stone output (107Mt) in 2009 [3]. If considered the ratio between production and inhabitants, than Portugal is largely the biggest producer among the top ten producers, with almost $30 \mathrm{~kg} /$ person.year [3]. South of Portugal produces a significant amount of quarry stone (Fig. 2 b) ), especially marbles and limestone, but also schists, due to the natural presence of these elements on the soil.

TABLE I: QUARRY STONE PRODUCTION (BY DECREASE ORDER)

\begin{tabular}{|c|c|c|c|}
\hline & $\begin{array}{c}\text { Production in } \\
2009 \\
\text { (kTon } \\
\text { /year)* }\end{array}$ & $\begin{array}{c}\text { Total } \\
\text { population } \\
\text { in 2009 (half } \\
\text { of the } \\
\text { year)** } \\
1000\end{array}$ & $\begin{array}{c}\text { Quarry stone } \\
\text { production } \\
\text { per-capita } \\
\text { (kg/person.year) }\end{array}$ \\
\hline 1- China & 2300,5 & 1.338 .613 & 1,7 \\
\hline 2- India & 2107,9 & 1.166 .079 & 1,8 \\
\hline 3- Turkey & 1155,6 & 76,805 & 15,0 \\
\hline 4- Iran & 1112,8 & 66,429 & 16,7 \\
\hline 5- Italy & 909,5 & 58,126 & 15,6 \\
\hline 6- Brazil & 749,0 & 198,739 & 3,8 \\
\hline 7- Spain & 716,9 & 40.525 & 17,7 \\
\hline 8- Egypt & 363,8 & 83,083 & 4,4 \\
\hline 9- Portugal & $\mathbf{3 1 0 , 3}$ & $\mathbf{1 0 . 7 0 8}$ & $\mathbf{2 8 , 9}$ \\
\hline 10- U.S.A. & 181,9 & 307.212 & 0,6 \\
\hline
\end{tabular}

*http://www.hkexnews.hk/listedco/listconews/sehk/2011/0307/01380_1017 369/E114.pdf

**http://www.indexmundi.com/
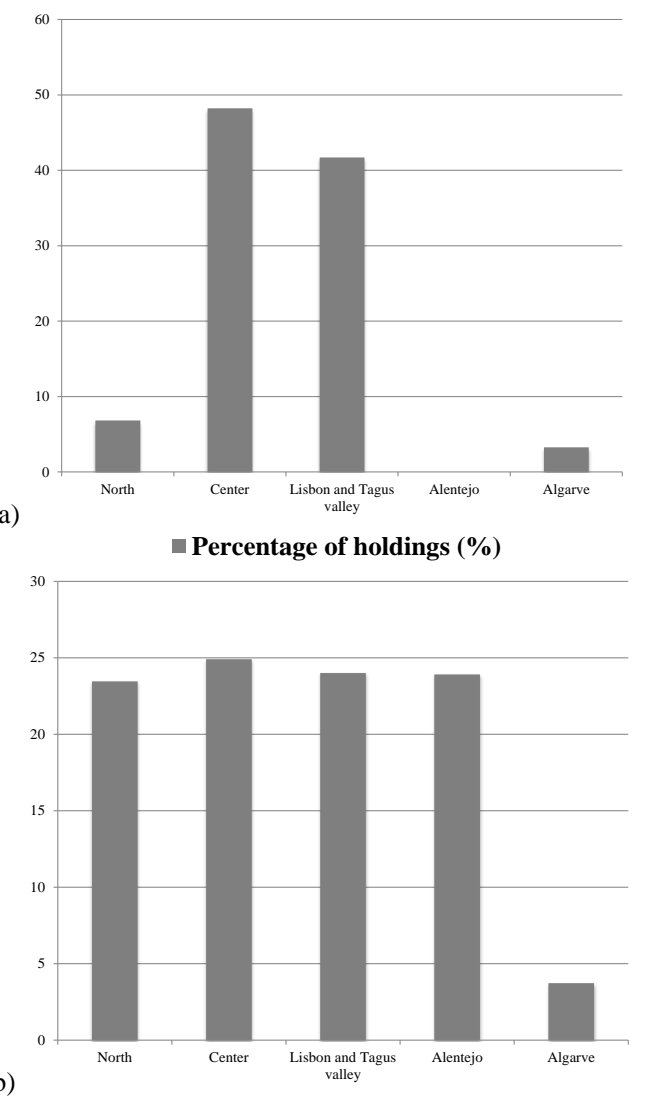

Fig. 2. Distribution (in \%) of the Portuguese national total: a) brick and b) quarry stone production by NUTII regions. Adapted from LNEG www.lneg.pt [3].

\section{Timber Construction}

Wood was almost the only material used in the construction of pavements and roof structures till the 
beginning of the twentieth century in Portugal. In urban context, even heavyweight earth or stone walls were reinforced in whole or in part with a wooden skeleton embedded inside in order to increase the overall load bearing capacity of the wall and decrease its thickness [4]. This construction system was brought to a high degree of complexity in the case of the reconstruction of downtown Lisbon, the capital of Portugal, destroyed after an earthquake in 1755. Nowadays, timber construction is increasing its market quota, especially due to the growing demand on prefabricated modular single housing. In 2009, the volume of roundwood extraction was the $10^{\text {th }}$ biggest in Europe, as it can be seen on Table II.

TABLE II: EUROPEAN INDUSTRIAL ROUNDWOOD EXTRACTION (BY DECREASE ORDER)

\begin{tabular}{|c|c|c|c|}
\hline & $\begin{array}{c}\text { Roundwood } \\
\text { removals in } \\
2009 \\
\left(1000 \mathrm{~m}^{3}\right. \\
\text { /year })^{*}\end{array}$ & $\begin{array}{c}\text { Total } \\
\text { population } \\
\text { in } 2009 \text { (half } \\
\text { of the } \\
\text { year) }{ }^{* *} \times \\
1000\end{array}$ & $\begin{array}{l}\text { Roundwood } \\
\text { removals per-capita } \\
\text { (m3/person.year) }\end{array}$ \\
\hline 1- Sweden & 66.300 & 9,060 & 7,3 \\
\hline 2 - Finland & 45.977 & 5,250 & 8,8 \\
\hline 3- Germany & 45.388 & 82,330 & 0,5 \\
\hline 4- Poland & 31.343 & 38,483 & 0,8 \\
\hline 5- France & 29.634 & 64,058 & 0,5 \\
\hline 6- Turkey & 15.695 & 76,805 & 0,2 \\
\hline 7- Czech Republic & 14.771 & 10,212 & 1,4 \\
\hline 8- Austria & 12.144 & 8,210 & 1,5 \\
\hline 9- Spain & 11.900 & 40.525 & 0,3 \\
\hline 10- Portugal & 8.964 & 10.708 & $\mathbf{0 , 8}$ \\
\hline
\end{tabular}

In Portugal, the housing buildings with vegetable materials comprise three different types:

- Buildings with roof in vegetable materials and stone or earth masonry wall with circular or rectangular plan. The circular plan was the characteristic typology of the Hill forts and "Citânias" of the Iron Age. This typology will evolve into a rectangular volume, with gabled roof. The rectangular volume, in its most elaborate forms, is the initial type of further traditional house, larger and with better living conditions;

- Buildings with wall-roof in vegetable materials, circular plan (conical) or rectangular. In this type, built entirely on vegetable materials, the roof extends to the ground and is an extremely primitive form derived from shelters that man has built in the Paleolithic. In Portugal, this type of construction was associated to the first fixed settlements in the Mesolithic and especially in the Neolithic, when man was already dedicated to agriculture and livestock [5]. The gable roof appear later than the conical and is more common on the coast, linked to fishing activity in the Alentejo coast, the Algarve and Tagus valley regions basket weavers houses - but also inland in the interior Centre region, connected to agriculture used for example as barns;

- Buildings entirely in vegetable materials with differentiated wall and roof. This type presents a cylindrical volume with a conical shaped roof or rectangular volume with gable roof. An example of this type is the "Curveiro," a dwelling with a cylindrical conical shape [5]. For corn drying in the Northwest of Portugal, the granaries also have a cylindrical volume which developed later into a rectangular volume (Fig. 3). The rectangular shape in this type appears in housing of coastal areas of portuguese centre region from Espinho to Vieira de Leiria initially, having later extended to the south - Algarve, Alentejo, Tagus valley and the Sado estuary. The huts of Carrasqueira, the case study presented in this paper, are buildings of this type located close to the Sado margins near Alcácer do Sal in the south of Lisbon (Fig. 4).

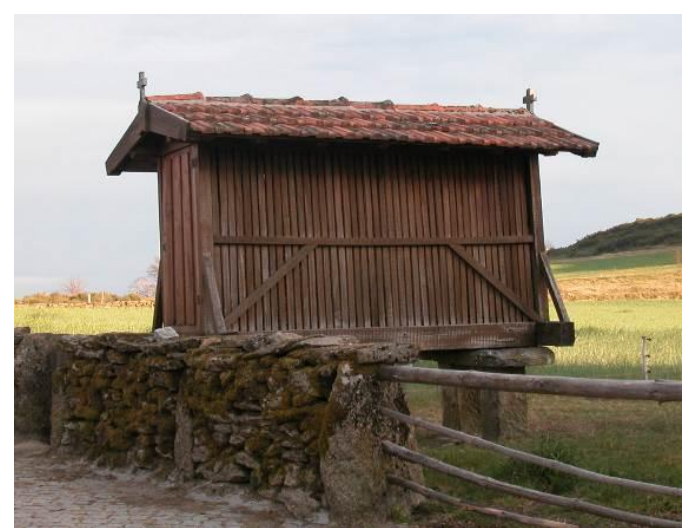

Fig. 3. Granaries for cereal drying in Boticas.

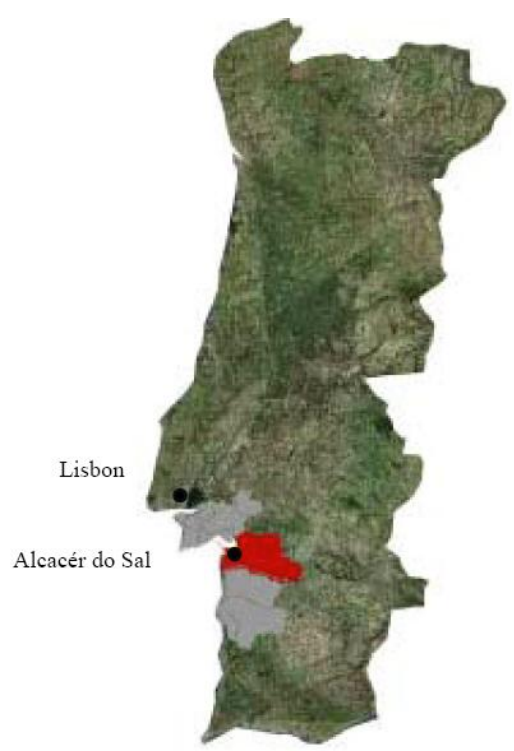

Fig. 4. Map of Portugal showing the location of Carrasqueira (Alcácer do Sa municipality is shown in red).

\section{THE CARRASQUEIRA HUT}

\section{A. Location of Carrasqueira}

The Carrasqueira huts arose from the need to build shelters for workers in rice paddies at the end of the $\mathrm{XIX}^{\text {th }}$ century; however a few of them may also be connected to the fishing activities. The first fisheries had already begun in the early sixteenth century, so some huts could begin to emerge already at this time [6]. In the middle of the $\mathrm{XX}^{\text {th }}$ century a stilt harbor formed by several wooden walkways was created in Carrasqueira.

The workers fixed for long periods of time and some families ended by permanently establish in this territory; as the landlord forbid them to build with durable materials they adopted the thatched straw to cover both the roof and walls. The implementation of the huts was designed according to the morphological characteristics of the plot. The ground 
should be flat and with little vegetation. Higher points were avoided, due to their excessive sun and wind exposure. Lower areas were also more fertile and abundant in resources. The small openings were designed to capture the natural light and promote ventilation, necessary to keep the vegetable coating materials free of any fungus or rot [7].

The Carrasqueira hut architecture (Fig. 5) is strongly linked to the traditional knowledge, transmitted through generations. This type of construction is closely linked to the human scale, where the proportions of all the elements are linked to the inhabitant in order to provide convenience and adaptability in the daily use. a)

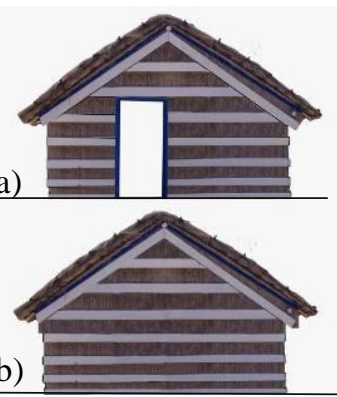

c)
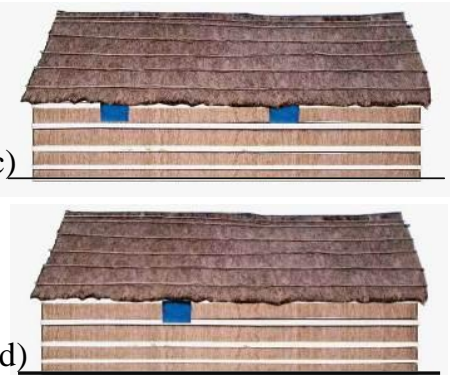

Fig. 5. Carrasqueira hut: a) Entrance façade; b) Back façade; c) and d) Side façades.

\section{B. Typology of the Carrasqueira Hut}

The entrance could be made from the top or the side façades, but always facing east (Fig. 6). Entering from the top allows the space to be more fluid and unitary. When entering from the side, the space is automatically divided into two areas, facilitating the distribution. The huts were of reduced dimensions without partitioning or with only two compartments. In the first case, the surface area ranged from 20 to $30 \mathrm{~m}^{2}$ and the interior spaces were only defined by the furniture [7]. The area near the entrance had a more public character, where eating and living allowed communion between indoor and outdoor spaces. Furthest from the entrance were the sleeping, dressing and hygiene areas, of a more private character.

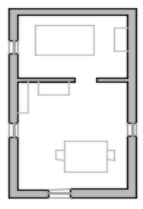

in

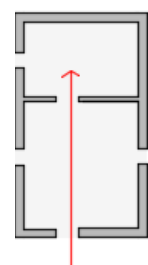

a)

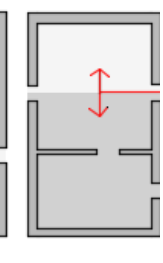

b)

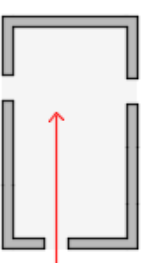

c)

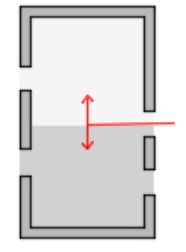

Fig. 6. Carrasqueira hut: a) Plan of a two compartment hut with furniture; b) Schemes of entrance and distribution: two compartment hut; c) one compartment hut.

\section{Building Construction Process}

The plan is rectangular and the structure of these buildings is in wood. The walls and roof are both in thatched straw, however the roof is made using a thinner stem to increase impermeability. The thatch can be attached to the wooden structure stitching it into small bundles wired to reeds or it can be spread over the surface and secured with a board or rod that is attached to the main structure by ropes or nails, being this technique called "valadio" [7]. Inside, the walls can be plastered with lime mortar, covered with reeds or with wooden boards (Fig. 7). When being plastered, a thinner thatch made with Corema Album plant is superposed and subsequently plastered with earth and lime slurry. Another option could be to place rods horizontally attached to the main structure and then placing the earthen and lime plaster [8]. The openings have a timber frame. Doors have a wicket and the windows, of small size, have interior shutters. They can be painted, usually in blue or red, and the boards or rods that support the thatch are painted in white, both outside and inside. It has no chimney, as there was no kitchen inside, and the floor was in compacted soil or in clay tiles [6].
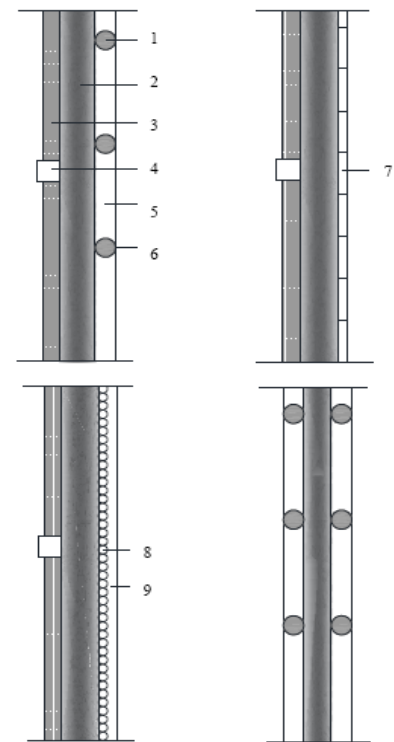

Fig. 7. Different thatched straw wall types used found in Carrasqueira huts: 1- Wood rods; 2- Grass thatch; 3- Straw thatch; 4- Purlin; 5- Earth plaster; 6 Lime slurry; 7- Boards; 8-Corema Album thatch; 9- Earthen plaster.

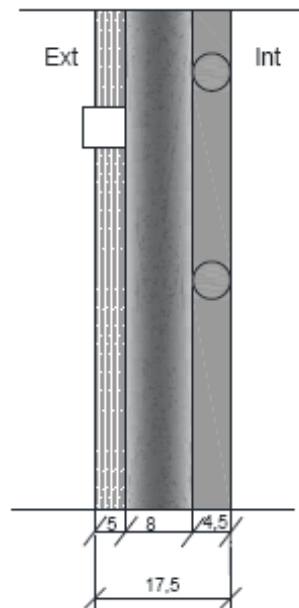

a). $\mathrm{U}\left(\mathrm{W} / \mathrm{m}^{2}{ }^{\circ} \mathrm{C}\right)=0,50 ; \mathrm{Rw}(\mathrm{dB})=60$

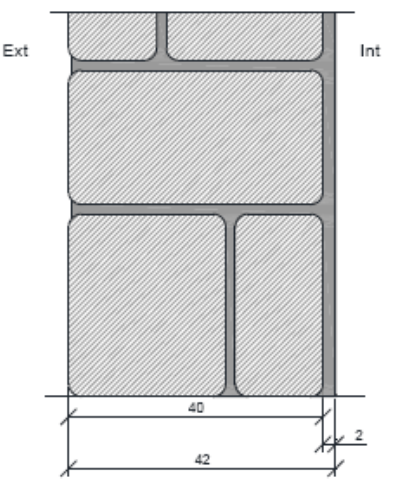

b). $U\left(W / m^{2}{ }^{\circ} \mathrm{C}\right)=3,05 ; \mathrm{Rw}(\mathrm{dB})=53$ 


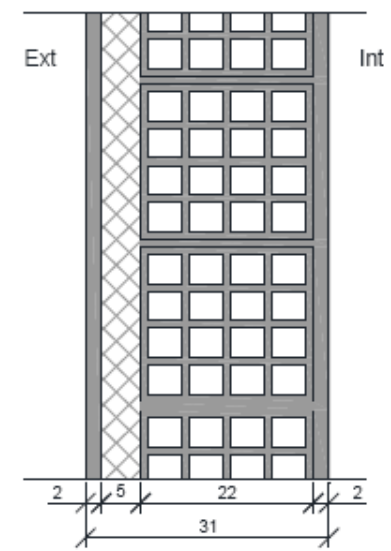

c). $\mathrm{U}\left(\mathrm{W} / \mathrm{m}^{2}{ }^{\circ} \mathrm{C}\right)=0,44 ; \operatorname{Rw}(\mathrm{dB})=62$

Fig. 8. Studied walls: a) Thatched straw wall; b) Simple stone masonry wall; c) Simple hollow brick wall with external EPS insulation (ETIC system).

Fig. 8 present sections of the exterior walls analyzed, with a summary of the respective thermal and acoustic insulation values. The windows size and materials were kept constant.

The one compartment Carrasqueira hut considered for the analysis, with $20 \mathrm{~m}^{2}$, corresponds to the average area of a habitable compartment in Portugal [2].

\section{ANALYSIS OF RESUlTS}

On Table III are presented the estimated considered environmental indicators by $\mathrm{m}^{2}$ of useful pavement area of the $20 \mathrm{~m}^{2}$ dwellings using 3 different constructive solutions: the conventional contemporary (post and beam concrete structure with clay hollow brick in walls and clay hollow blocks in pavement slabs; timber roof structure with clay tiles); the conventional traditional (stone masonry walls and timber roof structure with clay tiles) and the straw hut of Carrasqueira (timber structure with thatched straw both in walls and roof). In all solutions the pavement slab and foundations were considered to be in steel reinforced concrete in order to allow the comparison in more equal terms (foundations adapted to all types of soil for the requirements of a contemporary building).

TABLE III: ESTIMATED ENVIRONMENTAL INDICATORS OF THE BUILDING WITH THE ANALYZED EXTERNAL WALL AND ROOF SOLUTIONS

\begin{tabular}{|r|c|c|c|}
\hline & $\begin{array}{c}\text { Conventional } \\
\text { Concrete + clay } \\
\text { brick and block }\end{array}$ & $\begin{array}{c}\text { Traditional } \\
\text { Stone + timber } \\
\text { building }\end{array}$ & $\begin{array}{c}\text { Thatched Straw }+ \\
\text { timber building }\end{array}$ \\
\hline $\begin{array}{r}\text { Weight } \\
\left(\mathrm{kg} / \mathrm{m}^{2} \text { u.p.a.*) }\right.\end{array}$ & 1.418 & $2.881(+200 \%)$ & $1.077(-12 \%)$ \\
\hline $\begin{array}{r}\mathrm{EE} \\
\left(\mathrm{kWh} / \mathrm{m}^{2} \text { u.p.a.*) }\right.\end{array}$ & 961 & $627(-35 \%)$ & $452(-53 \%)$ \\
\hline $\begin{array}{r}\text { GWP** } \\
\left(\mathrm{g} / \mathrm{m}^{2} \text { u.p.a.*) }\right.\end{array}$ & 160.569 & $144.284(-10 \%)$ & $92.010(-43 \%)$ \\
\hline $\begin{array}{r}\text { AP*** } \\
\left(\mathrm{g} / \mathrm{m}^{2} \text { u.p.a.*) }\right.\end{array}$ & 3.343 & $1.901(-43 \%)$ & $1.329(-60 \%)$ \\
\hline $\begin{array}{r}\text { COD***** } \\
\left(\mathrm{g} / \mathrm{m}^{2} \text { u.p.a.*) }\right.\end{array}$ & 5.557 & $2.004(-64 \%)$ & $564(-90 \%)$ \\
\hline
\end{tabular}

* u.p.a.: useful pavement area; ** GWP - Global Warming Potential in grams of equivalent $\mathrm{CO}_{2} ; * * * \mathrm{AP}-$ Acid potential in grams of $\mathrm{SO}_{2} ; * * * *$ COD - Chemical Oxygen Depletion in grams of $\mathrm{NO}_{x}$; EE, GWP, AP and COD all reference values adapted from B. Berge "The Ecology of Building Materials"

http://ecobooks.greenharmonyhome.com/wp-content/uploads/ecobooks/Eco logy_of_Building_Materials_Second_Edition.pdf except for straw that were adapted from http://projekter.aau.dk/projekter/files/76859509/2013SEPM4 Ranjan_Parajuli.pdf

By the analysis of Table III, it can be concluded that the use of thatched straw can easily allow a reduction of $50 \%$ in
Embodied Energy, 40\% in Global Warming Potential, 60\% in Acid Potential and $90 \%$ in Chemical Oxygen Depletion in relation to the conventional hollow brick walls with concrete post and beam structure, even considering a timber structure for the roof.

\section{CONCLUSIONS}

Both the contemporary solution and the thatched straw are adequate to present Portuguese thermal regulations in terms of $U$ value for the majority areas of south Portugal. All the solutions are adequate to Portuguese acoustic regulation. Regarding all the environmental aspects considered, the dwelling built with natural vegetable materials come out as more environmentally sustainable, in terms of construction phase costs, than the conventional solution in hollow brick and concrete structure and even the traditional solution in stone masonry.

\section{REFERENCES}

[1] P. Mendonca, "Living under a second skin — Strategies for the environmental impact reduction of solar passive constructions in temperate climates," PhD thesis, University of Minho, 2005.

[2] INE, "Statistics of construction and housing in Portugal 2013," INE, Edition 2014.

[3] P. Mendonça and B. Martins, "Environmental impact reduction from using local natural construction materials: Case study in the North of Portugal," International Journal of Environmental Science and Development, vol. 6, no. 11, pp. 833-837, November 2015.

[4] F. Pinho, “Old buildings' walls in Portugal," LNEC, Lisboa, 2000.

[5] E. V. Oliveira and E. F. Galhano, Portuguese Traditional Architecture, $4^{\text {th }}$ edition, Publicações D. Quixote, Lisbon, 2000.

[6] E. V. Oliveira, F. Galhano, and B. Pereira, Primitive Buildings in Portugal, $3^{\text {th }}$ edition, Lisboa: Publicações D. Quixote, ISBN: 972-20-0196-5, 1994.

[7] M. Pires, "Architecture of sado estuary huts: Forms and livings of vernacular spaces," MSc thesis in architecture, Lisbon, 2013.

[8] P. Bruno and P. Faria, "Huts in vegetable materials on herdade da comporta," Building Traditions and New Approaches, Argumentum, Lisbon, pp. 240-243, 2010.

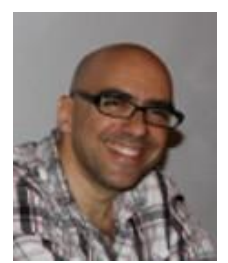

Paulo Mendonça was born in Porto on June 10, 1969. He received his $\mathrm{PhD}$ in civil engineering from the University of Minho, with the thesis: "Living under a second skin". With a PhD fellowship from FCT (Portuguese Foundation for Science and Technology), he got the "advanced studies diploma" in Barcelona on the Technical Superior School of Architecture (ETSAB). He was a JNICT (former FCT) fellowship student in the Textile Engineer Department of the University of Minho, where he obtained the master degree defending a thesis about "Intelligent textiles in architecture" (1997).

$\mathrm{He}$ is an associate professor in the Architecture School of the University of Minho, Portugal (EAUM) and the coordinator of the research group DeTech of the Lab2PT Centre. He was the president of EAUM (2011-2012) and the vice-president (2010-2011). He is the author of three patents of invention. The main research subjects include lightweight and mixed weight buildings, low cost housing etc.

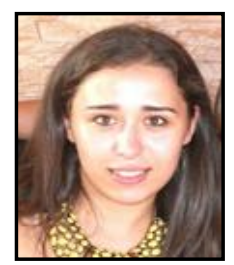

Francisca Amorim was born in Ponte de Lima on March 13, 1992. She is a master student of the Architecture School of the University of Minho, Portugal. The main research subjects include the use of vegetable materials in buildings, sustainable development, new materials and technologies. She is presently developing a master thesis titled "Vegetation on the exterior envelope of buildings: Impacts, constraints and eco-efficient intervention strategies". It seeks to develop a modular housing structure with vegetable materials, easy to build, which can be assembled in different ways and capable of being expanded and at the same time allowing the building to spend the minimum energy possible both in construction as well as on the use phases. 